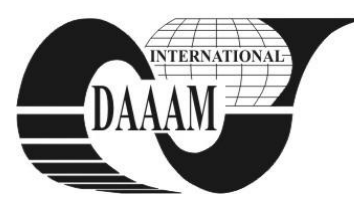

Annals of DAAAM for 2011 \& Proceedings of the 22nd International DAAAM Symposium, Volume 22, No. 1, ISSN 1726-9679 ISBN 978-3-901509-83-4, Editor B. Katalinic, Published by DAAAM International, Vienna, Austria, EU, 2011 Make Harmony between Technology and Nature, and Your Mind will Fly Free as a Bird Annals \& Proceedings of DAAAM International 2011

\title{
FIRE FIGHTING FOAMS AND THE ENVIRONMENT
}

\section{TUREKOVA, I[vana]; BALOG, K[arol] \& RUSKO, M[iroslav]}

\begin{abstract}
Extinguishing foams are commonly used for extinguishing the fire of flammable liquids, whereby their insulating, choking and quenching effects are exploited. The purpose of this paper is to consider and compare foams currently used in fire departments, with respect mainly to their high extinguishing effect (capability of faster aborted burning on a large surface at low foam consumption), but also their impact on the environment in each stage of their life cycle.

Key words: foams, fire extinguisher, fire, extinguishing properties, biodegradability
\end{abstract}

\section{INTRODUCTION}

Extinguishing agents are various substances and materials used to stop (slow down) the combustion process. Basic requirements for extinguishing agents are as follows:

- they must have high fire effects (the ability to quickly stop the burning of large areas at low consumption),

- they must not be harmful to human (living) organisms, when used or stored,

- they must be available at a reasonable price, etc.

Solution of used biodegradability fire-fighting foams has been the subject of the projects VEGA and with application in fire units.

Fire-fighting foam is an extinguishing agent composed of numerous bubbles formed mechanically or chemically from liquid. Chemical foam is formed by the reaction of alkaline solution with acidic solution in the presence of a foam stabilizer. Mechanical foam is formed after introducing air and/or inert gas into a foaming solution.

Foams belong to two-phase disperse systems consisting of dispersive media (liquid) with a dispersed phase - threedimensional lamellae of permanent structure containing enclosed gas. Plate thickness ranges from 0.001 to $0.01 \mathrm{~mm}$.

Foam fire effects consist of the following physical principles (Fig. 1.):

- Isolation - separate flammable substance from flame,

- Choky - prevents access of air oxygen to the flammable substance, prevents the evaporation of flammable liquids,

- Refrigerating - reduces the temperature of the burning substance and consequently slows down burning, which is directly proportional to the water content of the foam.

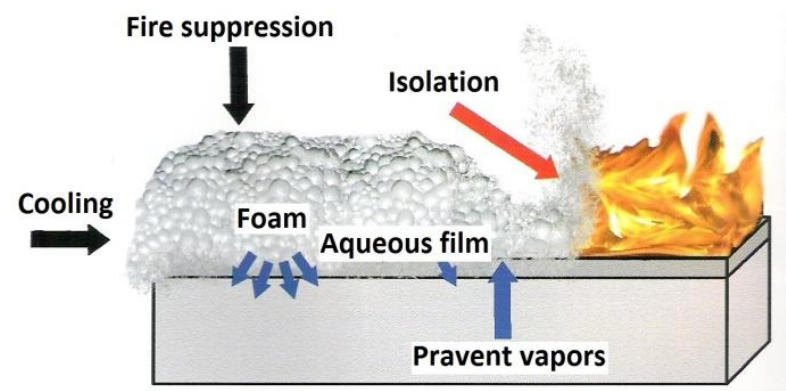

Fig. 1. Scheme of the mechanism of extinguishing using foam

\section{EXPERIMENTAL}

The aim of the experiment was to assess the extinguishing properties of foamers in the laboratory, and subsequently verify their impact on the environment in an experimental way. The following measurements were therefore made:

- monitoring the numbers of frothing and foaming time,

- determining the half-life,

- determining viscosity,

- determining the biochemical and chemical oxygen consumption,

- carrying out ecotoxicological tests on higher plants.

The following foamers were used in the experiment (Tab. 1):

\begin{tabular}{|c|c|c|c|c|}
\hline $\begin{array}{c}\text { Name of } \\
\text { foamer }\end{array}$ & Producer & for fires & \begin{tabular}{|c|}
$\begin{array}{c}\text { Concen- } \\
\text { tration }\end{array}$ \\
\end{tabular} & Notes \\
\hline $\begin{array}{c}\text { Sthamex } \\
\text { AFFF } \\
1 \%\end{array}$ & $\begin{array}{l}\text { Fabrik chemischer } \\
\text { Präparate von Dr. } \\
\text { Richard Sthamer } \\
\text { GmbH \& Co.KG, } \\
\text { Hamburg, Germany }\end{array}$ & $\mathrm{A}$ a B & $1 \%$ & \begin{tabular}{|l|} 
specially \\
designed for \\
hydrocarbon \\
fires, plastics \\
and mineral \\
oil products \\
\end{tabular} \\
\hline $\begin{array}{c}\text { Sthamex } \\
\text { AFFF } \\
\text { F-15 }\end{array}$ & $\begin{array}{l}\text { Fabrik chemischer } \\
\text { Präparate von Dr. } \\
\text { Richard Sthamer } \\
\text { GmbH \& Co.KG, } \\
\text { Hamburg, }\end{array}$ & $\mathrm{A}$ a B & $3 \%$ & $\begin{array}{|lr|}\text { Specially } & \\
\text { designed } & \text { for } \\
\text { fires of } & \text { oil } \\
\text { products } & \text { and } \\
\text { plastics } & \\
\end{array}$ \\
\hline Pyronil & $\begin{array}{c}\text { Chemtura Corporation, } \\
\text { USA }\end{array}$ & $\mathrm{A}$ a B & $3 \%$ & \begin{tabular}{|l|} 
Synthetic \\
multipurpose \\
foamer, also \\
light foam
\end{tabular} \\
\hline \multirow{2}{*}{$\begin{array}{l}\text { Moussol } \\
\text { APS F-15 }\end{array}$} & \multirow{2}{*}{$\begin{array}{l}\text { Fabrik chemischer } \\
\text { Präparate von Dr. } \\
\text { Richard Sthamer } \\
\text { GmbH \& Co.KG, } \\
\text { Hamburg, Germany }\end{array}$} & \multirow[t]{2}{*}{$\mathrm{A}$ a B } & $3 \%$ & $\begin{array}{l}\begin{array}{l}\text { Fire fighting } \\
\text { of liquid of } \\
\text { non-polar } \\
\text { hydrocarbons }\end{array} \\
\end{array}$ \\
\hline & & & $6 \%$ & \begin{tabular}{|l|} 
Fire fighting \\
of liquid of \\
polar \\
hydrocarbons
\end{tabular} \\
\hline
\end{tabular}

Tab. 1 Used foamers and their characteristics

The limitations of the research were used fire test methods available and used by the existing foams. The choice extinguishing foamers, procedures and tests was based not only on the fire characteristics, but also in relation to biodegradation. Their selection was based on the research findings available in HZZ. Foamers were prepared in five different concentrations (1 $\%, 3 \%, 6 \%, 9 \%$ and $12 \%)$.

\subsection{Number of foaming}

The number of foaming (E) was determined in accordance with STN EN 1568-3: 2002 standard Technical conditions of foamers for heavy foam on the surface use with the liquid immiscible with water. The determination comprised the number of frothing of selected foamers of different concentrations, and the time of foam formation (Tab. 2).

Number of frothing ranged around the value $4.9 \pm 0.1$ for all foamers, allowing a fair comparison of foaming time. The 
fastest foamed foamers Sthamex AFFF 1\%, AFFF Sthamex F-15, then Pyronil and the longest foaming time had Moussol APS F-15, in which time foaming at $1 \%$ concentration significantly extended.

\begin{tabular}{|c|c|c|c|c|c|c|}
\hline \multicolumn{2}{|c|}{$\begin{array}{l}\text { Concentration of } \\
\text { foamers [\%] }\end{array}$} & 12 & 9 & 6 & 3 & 1 \\
\hline \multirow{4}{*}{ 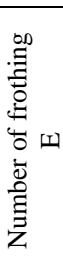 } & $\begin{array}{c}\text { Sthamex } \\
\text { AFFF } \\
1 \%\end{array}$ & 4,886 & 4,894 & 4,890 & 4,906 & 4,827 \\
\hline & $\begin{array}{c}\text { Sthamex } \\
\text { AFFF F-15 }\end{array}$ & 4,909 & 4,891 & 4,827 & 4,826 & 4,883 \\
\hline & Pyronil & 4,901 & 4,908 & 4,878 & 4,839 & 4,820 \\
\hline & $\begin{array}{c}\text { Moussol } \\
\text { APS F-15 }\end{array}$ & 4,822 & 4,854 & 4,887 & 4,837 & 4,807 \\
\hline \multirow{4}{*}{ 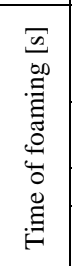 } & $\begin{array}{c}\text { Sthamex } \\
\text { AFFF } \\
1 \%\end{array}$ & 6,61 & 11,69 & 13,35 & 14,7 & 27,35 \\
\hline & $\begin{array}{c}\text { Sthamex } \\
\text { AFFF F-15 }\end{array}$ & 16,58 & 19,20 & 19,25 & 25,28 & 35,04 \\
\hline & Pyronil & 17,71 & 20,34 & 25,63 & 30,55 & 34,44 \\
\hline & $\begin{array}{c}\text { Moussol } \\
\text { APS F-15 }\end{array}$ & 19,23 & 23,38 & 26,20 & 30,24 & 57,81 \\
\hline
\end{tabular}

Tab. 2 Number of frothing and time of foaming tested foamers

\subsection{Half-life}

As regards the manufacturer recommendations in the safety data sheets, half-life was tested by using $3 \%$ solutions, while monitoring the time at which $50 \%$ of the foaming solution were released from the foam. The results of the measured values for each foamer are given in Tab. 3.

\begin{tabular}{|l|c|c|}
\hline No & Name of foamer & Half-life [s] \\
\hline 1. & Sthamex AFFF 1\% & 62 \\
\hline 2. & Sthamex AFFF F-15 & 166 \\
\hline 3. & Pyronil & 187 \\
\hline 4. & Moussol APS F-15 & 187 \\
\hline
\end{tabular}

Tab. 3 Half-life of tested foamers (3\% solutions)

The most favorable results were achieved with the use of foamers Pyronil and Moussol APS F-15 foamers, where the half-life was 187 seconds.

\subsection{Determination of biochemical oxygen demand}

The basic part of the test is treatment and dilution of water sample to be analyzed by different amounts of diluent water with a high amount of dissolved oxygen and vaccinic aerobic microorganisms with prevention of nitrification. Incubation was conducted at $20^{\circ} \mathrm{C}$ within a defined time of 5 days in the dark in a full closed flask. The dissolved oxygen concentration was determined before and after incubation according to STN EN 1899-1 Water quality - Determination of biochemical oxygen consumption after $\mathrm{n}$ days (BSKn): Part 1: Dilution and inoculation method with the addition of allylurea. Use was made of vaccinated diluting water, and dissolved oxygen was electrochemically determined (Tab. 4.).

\begin{tabular}{|c|c|c|c|}
\hline Name of foamer & $\begin{array}{c}\text { COD } \\
{\left[\mathrm{mg} . \mathrm{l}^{-1}\right]}\end{array}$ & $\begin{array}{c}\text { BOD5 } \\
{\left[\mathrm{mg} . \mathrm{l}^{-1}\right]}\end{array}$ & $\begin{array}{c}\text { BOD5/COD } \\
{[\%]}\end{array}$ \\
\hline Sthamex AFFF 1 \% & 76.23 & 22790 & 0.33 \\
\hline Sthamex AFFF F-15 & 73.68 & 21370 & 0.34 \\
\hline Pyronil & 79.20 & 33530 & 0.23 \\
\hline Moussol APS F-15 & 83.46 & 17470 & 0.47 \\
\hline
\end{tabular}

Tab. 4. Results of COD and BOD5 values tested foamers (3\% foreign solutions)

\subsection{Determination of chemical oxygen demand}

The oxidizable substances in the test sample volume are oxidized by a known quantity of potassium dichromate in the presence of mercuric sulfate and silver catalyst in an environment of concentrated sulfuric acid in a defined time interval. The COD value was calculated on the basis of the amount of reduced dichromate.

The indicator COD shows the total content of organic substances in water - organic water pollution (Tab. 4.).

The results of foamer biodegradability suggest that foamers have little ability to biological degradation due to a very small proportion of degradable substances.

\section{CONCLUSION}

Currently many types of fire-fighting foams different physical and extinguishing properties are known. Each of them has its own pros and cons, as was shown by our testing. It is necessary to know their physical characteristics, e.g. their stability at low and high temperatures defined by half-life; the number of foaming specifying whether it is heavy, medium or light foam, and also their viscosity, resistance of fluid to internal friction and other properties to be appropriately selected and used in fire-fighting practice.

Modern fire-fighting foams can be considered to be very good in terms of physical characteristics, but in recent years, the REACH legislation draws attention to their ecotoxicological properties. If fire-fighting foams are used to extinguish large fires, their products (such as decomposed water from the formed foam) are very likely to get into the soil and water flow, concurrently affecting the possibility of wastewater purification. All types of foam have different ecological characteristics since their components determine the rate of biodegradation. The ecotoxicological tests of Sinapis alba also showed that even a low concentration of foamer exhibits significant toxicity.

The research highlighted the need for an additional test. The aim of further research will be looking for fast and safe testing methods, not only physical and chemical properties of foamers but ekotoxical properties, too.

\section{ACKNOWLEDGEMENTS}

This contribution/ is the result of the project implementation: Centre of Excellence for the development and application of diagnostic methods in the processing of metallic and non-metallic materials, ITMS:26220120048, supported by the Research \& Development Operational Programme funded by the ERDF.

\section{REFERENCES}

Balog, K. (2004). Hasiace látky a jejich technológie, Edice SPBI Spektrum, ISBN 80-86634-49-3, Ostrava

Coneva, I. (2002). Fire Engineering Proceedings 1st International Conference, Pena - hasiaca látka. Technická univerzita, ISBN 80-89051-05-7, Zvolen

Jirkovská, V. (1988). Zborník prác požiarnotechnickej stanice, Posúdenie kvality penidiel, pp. 54-56

Marková, I. (2010) Požární ochrana 2010 : Sborník přednášek XIX. ročníku mezinárodní konference, Ostrava, VŠB - TU, 8.-9. záríi 2010, Determination of extinguishing effect of $F E$ 36 by CUP BURNER test - of principle of fire extinguishing of halon. Vysoká škola báňská - Technická univerzita V Ostravě, ISBN 978-80-7385-087-6, pp. 199 - 203

Mikušová, K. (2008). Fyzikálne vlastnosti penidiel. Spravodajca: Protipožiarna ochrana a záchranná služba, Vol. 39, No.3, pp. 24 - 29.

Orlíková, K. (2002). Hasiva klasická a moderní. Edice SPBI Spektrum, ISBN 80-86111-93-8, Ostrava

STN-EN 1568: 2002, Fire extinguishing media - Foam concentrates $1-4$ 